\title{
Numerical \& Analytical Modeling of Plasmonic Filter with High Q-Factor Based on "Nanostructured Resonator"
}

\section{Research Article}

Keywords:

Posted Date: May 20th, 2021

DOI: https://doi.org/10.21203/rs.3.rs-423230/v2

License: (c) (1) This work is licensed under a Creative Commons Attribution 4.0 International License. Read Full License

Version of Record: A version of this preprint was published at Plasmonics on September 14th, 2021. See the published version at https://doi.org/10.1007/s11468-021-01527-1. 


\section{Abstract}

The authors have requested that this preprint be withdrawn due to erroneous posting.

\section{Full Text}

The authors have withdrawn this preprint from Research Square. 